\title{
Population genetics analysis of Phytophthora nicotianae associated with heart rot in pineapple revealed geneflow between population
}

\author{
AULIANA AFANDI ${ }^{1,2}$, SITI SUBANDIYAH ${ }^{2,3,}$, ARIF WIBOWO $^{3}$, AYAKA HIENO $^{4}$, AFANDI $^{5}$, \\ SUPRIYONO LOEKITO ${ }^{6}$, HASRUHISA SUGA ${ }^{7}$, KOJI KAGEYAMA ${ }^{4}$ \\ ${ }^{1}$ Department of Plant Protection, Faculty of Agriculture, Universitas Lampung. Jl. Prof. Dr. Sumantri Brojonegoro No. 1, Bandar Lampung 35145, \\ Lampung, Indonesia \\ ${ }^{2}$ Program of Biotechnology, Universitas Gadjah Mada. Jl. Teknika Utara, Barek, Sleman 55281, Yogyakarta, Indonesia \\ ${ }^{3}$ Department of Entomology and Plant Pathology, Faculty of Agriculture, Universitas Gadjah Mada. Jl. Flora, Bulaksumur, Sleman 55281, Yogyakarta, \\ Indonesia. Tel.: +62-274-563062, 901290, Fax.: 62-274-563062, 519717, vemail: sitisubandiyah@ugm.ac.id \\ ${ }^{4}$ River Basin Research Center, Gifu University, 1-1 Yanagido, Gifu 501-1193, Gifu, Japan \\ ${ }^{5}$ Department of Soil Science, Faculty of Agriculture, Universitas Lampung. J1. Prof. Dr. Sumantri Brojonegoro No. 1, Bandar Lampung 35145, Lampung, \\ Indonesia \\ ${ }^{6}$ PT. Great Giant Pineapple. Jl. Raya Bandar Lampung-Menggala km. 77, Terbanggi Besar, Lampung Tengah 34165, Lampung, Indonesia \\ ${ }^{7}$ Life Science Research Center, Gifu University. 1-1 Yanagido, Gifu 501-1193, Gifu, Japan.
}

Manuscript received: 18 April 2021. Revision accepted: 21 July 2021.

\begin{abstract}
Afandi A, Subandiyah S, Wibowo A, Hieno A, Afandi, Loekito S, Suga H, Kageyama K. 2021. Population genetics analysis of Phytophthora nicotianae associated with heart rot in pineapple revealed gene flow between populations. Biodiversitas 22: $3342-3348$. Phytophthora nicotianae has caused heart rot in pineapple. This study identified the population genetic diversity of $P$. nicotianae, collecting 90 isolates of $P$. nicotianae from the pineapple plantation sites in three provinces of Indonesia and, as comparisons, seven isolates from non-pineapple sites. Six polymorphic microsatellite markers amplified the non-coding region was used to characterize the population diversity. The phylogenetic tree constructed by MEGA revealed three major clades; the first and second clades were dominated by the isolates from pineapple plantation sites, and the third clade contained isolates from the non-pineapple sites. The allelic pattern analysis using Genalex software revealed the local alleles specific to Lampung and Blitar populations. The AMOVA of microsatellite genotypes data showed that the isolates had a low diversity among the population (6\%) but high diversity within individual. Conclusively, $P$. nicotianae population associated with heart rot in pineapple showed geneflow between populations.
\end{abstract}

Keywords: Analysis of molecular variation, genetic variation, microsatellite, Phytophthora nicotianae, population structure

\section{INTRODUCTION}

Some pathogens cause heart rot in pineapple but the most common in Indonesia is Phytophthora nicotianae. Held responsible for drastically diminishing annual yield of fruit harvest (Ratti et al. 2018), this disease shows symptoms of soft rotting of the basal white tissues of the youngest leaves at the heart of the apical meristem. The infected leaves are easily pulled from the plant, and as the disease progresses sufficiently, the plants die. In fruitbearing plants of susceptible varieties, the infection can move up through the peduncle and rot the fruit (Green and Nelson 2015).

To suppress the pathogen, pineapple farmers maintain their soil $\mathrm{pH}$ below 3.8. Although seemingly effective in suppressing the growth of Phytophthora, applying this method for years in pineapple plantations can alter the soil microbiome condition and render severe soil damage in the future. Another safer method to control the pathogen is by dipping the seed materials in a fungicide suspension before planting (Radmer et al. 2017). However, recent studies reported the emergence of fungicide-resistant $P$. nicotianae among the natural population (Panabiries et al. 2016); an alarming sign for farmers who rely heavily on fungicide to treat the pathogen.
Phytophthora nicotianae has arachnoid branching mycelium and non-cadoucus sporangia (Bush et al. 2006). Most $P$. nicotianae isolates are heterothallic, and some can be homothallic. The antheridia are amphigynous and spherical or oval and 9-10 $\times 10-12 \mu \mathrm{m}$ in size (Waterhouse and Waterston, 1964a; 1964b). The Oogonia are smooth and spherical with a diameter of 15-64 $\mu \mathrm{m}$ (av. $26.8 \mu \mathrm{m}$ ), a 1-2 $\mu \mathrm{m}$ thick wall, and aplerotic oospores, 13-35 $\mu \mathrm{m}$ in diameter. This pathogen was first isolated in Indonesia in 1896 by de Haan. To date, P. nicotianae remains the most destructive plant pathogen with a broad range of hosts and habitats (Panabieres et al. 2016), responsible for $100 \%$ yield loss in tobacco and severe damage in citrus and tomato industries in Australia. As a soil-borne pathogen, $P$. nicotianae can be found indigenously in its natural environments, such as mountainous areas (Vettraino et al. 2009), forest soil (Jung et al. 2016), and irrigation water (Hong and Moorman 2005).

The characteristics of $P$. nicotianae population are specific according to geography and host. In South India, the host-specific lineages are reported on Brinjal, Ridge Gourd, and Tomato (Chowdappa et al. 2016). On the other hand, $P$. nicotianae population in Georgia is associated with geographical location ( $\mathrm{Li}$ et al. 2017). Interestingly, recent studies using various hosts and geographic locations 
across Japan reported the absence of geographical structure and suggested human facilitated migration (Afandi et al. 2019).

Population genetics research has used different genetic markers extensively, including mitochondrial DNA (mtDNA), random amplified polymorphic DNA (RAPD), amplified fragment length polymorphism (AFLP), single nucleotide polymorphism (SNP), and microsatellite markers.

To date, understanding the population structure of $P$. nicotianae collected from pineapple plantation that suffers from heart rot disease remains an issue. Although genetic variability within a population directly impacts the virulence and ecology of certain pathogens, a highly variable gene pool allows them to adapt more quickly to environmental change; hence, increasing their potential to produce new virulent variants. This study analyzed the population genetics of $P$. nicotianae causing heart rot disease in pineapple to better understand the disease management strategies.

\section{MATERIALS AND METHODS}

\section{Research sites}

Phytophthora nicotianae used in this study was part of the Gifu University Culture Collection. The isolates were collected from 39 locations at Central Lampung, Lampung Province; Blitar, East Java; Subang, West Java; and Pemalang, Central Java. In comparison, $P$. nicotianae isolated from the non-pineapple host were collected from Getasan, Godean, and Sleman (Table 1). The isolates were previously identified molecularly using ITS primer. The DNA extraction was performed at Biotechnology research center, Universitas Gadjah Mada, the microsatellite amplification was done at Oomycete Research Laboratory, River Basin Research Center, Gifu University, Japan and the fragment analysis was performed at genomic research laboratory, Life Science Research Center, Gifu University, Japan.

\section{DNA extraction}

The total DNA was extracted using the PrepMan Ultra Reagent (Applied Biosystem). First, the isolates were cultured at v8 medium to increase the hyphal growth. A small loopful of mycelia was transferred into $100 \mu \mathrm{l}$ of the PrepMan Ultra Sample Preparation Reagent in a microcentrifuge tube for a vigorous vortex for $30 \mathrm{~s}$. The tube was heated at $100{ }^{\circ} \mathrm{C}$ for 10 minutes and then spun in the microcentrifuge for 2 minutes at the highest speed. At last, $50 \mu \mathrm{l}$ of the supernatant was transferred to a new microcentrifuge tube and stored at $-4{ }^{\circ} \mathrm{C}$.

\section{Microsatellite genotyping}

Six polymorphic loci were used to analyze the $P$. nicotianae population (Afandi et al. 2019). The primers were labeled at the 5 ' end separately with two fluorescent dyes, FAM (6-carboxy-fluorescein), or HEX $\left(4,7,2^{\prime}, 4^{\prime}, 5^{\prime}, 7^{\prime}\right.$-hexachloro-6-carboxyfluorescein) (Lees et al.2006). All selected primers were administered to amplify DNA consecutively as follows: one cycle at $94^{\circ} \mathrm{C}$ for 5 min, 35 cycles at $94^{\circ} \mathrm{C}$ for $30 \mathrm{~s}, 58^{\circ} \mathrm{C}$ for $30 \mathrm{~s}, 72^{\circ} \mathrm{C}$ for 30 $\mathrm{s}$, and finally extended to $72^{\circ} \mathrm{C}$ for seven minutes. The total reaction volume was $25 \mu \mathrm{l}$ containing $2 \mu \mathrm{L} 1 \mathrm{ng}$ DNA, 2.5 $\mu \mathrm{L} 10 \times$ PCR buffer (Takara, Japan), $2.5 \mu \mathrm{l} 4 \mathrm{mg} / \mathrm{mL}$ BSA, $2.5 \mu \mathrm{L} 10 \mathrm{mM}$ primer forward and reverse, $2 \mu \mathrm{L} 2.5 \mathrm{mM}$ dNTP mix (Takara, Japan), $0.1 \mu \mathrm{L}$ rTaq polymerase (Takara, Japan), and $10.9 \mu \mathrm{L}$ ddH2O. The PCR amplification products were evaluated by GelRed staining (Biotium) using $2 \%$ agarose gel in $0.5 \times$ Tris-Acetate-EDTA buffer and observed under UV light. The LIZ 250 DNA ladder was utilized as a marker to analyze these fragments on the ABI3100 and ABI3130 genetic analyzers (Applied Biosystem), then the electropherogram was manually scored.

\section{Data analysis}

The genetic diversity analysis for this study included statistical analysis and phylogenetic tree construction. The statistical analysis was performed on molecular variance, allelic pattern across population, and the calculation of fixation index GenAlex 5.6.3 (Peakall and Smouse 2006 2012). The phylogenetic tree was constructed using the neighbor-joining algorithm by MEGA 6 (Tamura et al. 2013).

\section{RESULTS AND DISCUSSION}

In total, 97 isolates of $P$. nicotianae were collected for genetic diversity using six microsatellite markers: 90 from diseased pineapple plant or rhizosphere and seven from the non-pineapple, for comparison (Table 1). The isolates associated with heart rot disease in pineapple were collected in four provinces in Indonesia, namely 41 isolates in Lampung (Terbanggi Besar and Punggur area), ten isolates in West Java (Subang area), eight isolates in Central Java (Pemalang area), and 31 isolates in East Java (Blitar area). The non-pineapple isolates were collected from chrysanthemum in Sleman, chili and tobacco in Getasan, and cabbage in Dieng.

A total of 27 multilocus genotypes (MLGs) were observed from six groups of $P$. nicotianae populations represented by 97 isolates (Table 2). A multilocus genotype is a unique combination of alleles that span two or more loci. For $P$. nicotianae that most likely reproduce asexually, multilocus genotypes are extremely valuable for identifying the pattern and spread of the pathogen (Kamvar and Grunwald 2021). The highest number of MLG was found in $P$. nicotianae population collected in Central Lampung (12), followed by Blitar (10), the non-pineapple group (6), Pemalang (5), Subang (2), and the least was Punggur (1). The high number of MLG in one population illustrates the high variability of $P$. nicotianae. In this case, the Central Lampung population had the highest variability. 
Table 1. Phytophthora nicotianae isolates from pineapple and other plant hosts

\begin{tabular}{|c|c|c|c|}
\hline Collection code & Origin & Host plant & $\begin{array}{c}\text { Isolation } \\
\text { year }\end{array}$ \\
\hline AA 129D 2 & Central Lampung & Pineapple & 2016 \\
\hline AA 71 A S1 & Central Lampung & Pineapple & 2016 \\
\hline AA $114 \mathrm{~K}$ HS 2 & Central Lampung & Pineapple & 2016 \\
\hline AA 71A 2 & Central Lampung & Pineapple & 2016 \\
\hline AA $36 \mathrm{G}$ & Central Lampung & Pineapple & 2016 \\
\hline TBC GTS & Getasan & Tobacco & 2016 \\
\hline AA $71 \mathrm{~A} 3$ & Central Lampung & Pineapple & 2016 \\
\hline TBC GTS 4 & Getasan & Tobacco & 2016 \\
\hline AA $10 \mathrm{~A} 1$ & Central Lampung & Pineapple & 2016 \\
\hline AA $114 \mathrm{~K}$ HS 1 & Central Lampung & Pineapple & 2016 \\
\hline AA $114 \mathrm{~K}$ HS 3 & Central Lampung & Pineapple & 2016 \\
\hline AA $114 \mathrm{~K} \mathrm{~S} 3$ & Central Lampung & Pineapple & 2016 \\
\hline AA $114 K$ S2 & Central Lampung & Pineapple & 2016 \\
\hline AA 129D 1 & Central Lampung & Pineapple & 2016 \\
\hline AA 129D4 & Central Lampung & Pineapple & 2016 \\
\hline AA $35 \mathrm{~A} 1$ & Central Lampung & Pineapple & 2016 \\
\hline AA NIA $S$ & Central Lampung & Pineapple & 2016 \\
\hline $\mathrm{AA} 36 \mathrm{G} 1 \mathrm{~A}$ & Central Lampung & Pineapple & 2016 \\
\hline AA 71A S1 & Central Lampung & Pineapple & 2016 \\
\hline AA71A 3 & Central Lampung & Pineapple & 2016 \\
\hline ORC GOD & Godean & Orchid & 2016 \\
\hline CHL KDT A & Getasan & Chili & 2016 \\
\hline CHL S A2 & Sleman & Chili & 2016 \\
\hline AA 51402R01 & Central Lampung & Pineapple & 2016 \\
\hline $\mathrm{CS} \mathrm{GH} 22$ & Sleman & Chrysanthemum & 2016 \\
\hline $\mathrm{CS}$ GH3 1 & Sleman & Chrysanthemum & 2016 \\
\hline CBG DIENG 1-1 & Dieng & Cabbage & 2016 \\
\hline $51402 \mathrm{R} 2 \mathrm{~b}$ & Central Lampung & Pineapple & 2016 \\
\hline aa 71 a 2 b & Central Lampung & Pineapple & 2016 \\
\hline aa $25 \mathrm{a} 06 \mathrm{pt} 1$ & Central Lampung & Pineapple & 2016 \\
\hline AA 36 G 2 A & Central Lampung & Pineapple & 2016 \\
\hline NBRC 31423 & Taiwan & Pineapple & 1984 \\
\hline 155 A 3 & Blitar & Pineapple & 2018 \\
\hline B156 C3 & Blitar & Pineapple & 2018 \\
\hline P31C & Pemalang & Pineapple & 2018 \\
\hline 155 A 2 & Blitar & Pineapple & 2018 \\
\hline PUNG 362 & Punggur & Pineapple & 2018 \\
\hline B 151 B3 & Blitar & Pineapple & 2018 \\
\hline B 156 B2 & Blitar & Pineapple & 2018 \\
\hline B $159 \mathrm{C}$ & Blitar & Pineapple & 2018 \\
\hline S 69 & Subang & Pineapple & 2018 \\
\hline B $156 \mathrm{C}$ & Blitar & Pineapple & 2018 \\
\hline S 63 & Subang & Pineapple & 2018 \\
\hline PUNG 1522 & Punggur & Pineapple & 2018 \\
\hline B $150 \mathrm{~A}$ & Blitar & Pineapple & 2018 \\
\hline B 154 B1 & Blitar & Pineapple & 2018 \\
\hline B 156 A2 & Blitar & Pineapple & 2018 \\
\hline B 157 A 2 & Blitar & Pineapple & 2018 \\
\hline PUNG $182 \mathrm{~N}$ & Punggur & Pineapple & 2018 \\
\hline B 156 C2 & Blitar & Pineapple & 2018 \\
\hline $1725 \mathrm{~A} 3$ & Central Lampung & Pineapple & 2017 \\
\hline $17124 \mathrm{C} 3$ & Central Lampung & Pineapple & 2017 \\
\hline $1725 \mathrm{~A} 06$ & Central Lampung & Pineapple & 2017 \\
\hline $17114 \mathrm{~K} 2$ & Central Lampung & Pineapple & 2017 \\
\hline 1736G2 & Central Lampung & Pineapple & 2017 \\
\hline 129D1 & Central Lampung & Pineapple & 2017 \\
\hline $17124 \mathrm{D} 2$ & Central Lampung & Pineapple & 2017 \\
\hline 17514042 & Central Lampung & Pineapple & 2017 \\
\hline P32B & Pemalang & Pineapple & 2017 \\
\hline B156B3 & Blitar & Pineapple & 2018 \\
\hline $159 \mathrm{C} 2$ & Blitar & Pineapple & 2018 \\
\hline $\mathrm{B} 156 \mathrm{C} 2$ & Blitar & Pineapple & 2018 \\
\hline
\end{tabular}

\begin{tabular}{|c|c|c|c|}
\hline $151 \mathrm{~A} 1$ & Blitar & Pineapple & 2018 \\
\hline 155A1 & Blitar & Pineapple & 2018 \\
\hline B157B3 & Blitar & Pineapple & 2018 \\
\hline 153B1 & Blitar & Pineapple & 2018 \\
\hline $159 \mathrm{C} 2$ & Blitar & Pineapple & 2018 \\
\hline $153 \mathrm{~A} 2$ & Blitar & Pineapple & 2018 \\
\hline 159A1 & Blitar & Pineapple & 2018 \\
\hline $151 \mathrm{C}$ & Blitar & Pineapple & 2018 \\
\hline 157A1 & Blitar & Pineapple & 2018 \\
\hline $156 \mathrm{C} 3$ & Blitar & Pineapple & 2018 \\
\hline 155A1 & Blitar & Pineapple & 2018 \\
\hline B154C2 & Blitar & Pineapple & 2018 \\
\hline B156C1 & Blitar & Pineapple & 2018 \\
\hline 157A2 & Blitar & Pineapple & 2018 \\
\hline $155 \mathrm{~A} 3$ & Blitar & Pineapple & 2018 \\
\hline B157B2 & Blitar & Pineapple & 2018 \\
\hline 1771A1 & Central Lampung & Pineapple & 2017 \\
\hline P3B2 & Pemalang & Pineapple & 2018 \\
\hline 1736G3 & Central Lampung & Pineapple & 2017 \\
\hline S51 & Subang & Pineapple & 2018 \\
\hline 1736G1B & Central Lampung & Pineapple & 2017 \\
\hline $1725 \mathrm{~A} 062$ & Central Lampung & Pineapple & 2017 \\
\hline P31B & Pemalang & Pineapple & 2018 \\
\hline S33A & Subang & Pineapple & 2018 \\
\hline S1R2 & Subang & Pineapple & 2018 \\
\hline P31E & Pemalang & Pineapple & 2018 \\
\hline $1710 \mathrm{~A} 7$ & Central Lampung & Pineapple & 2017 \\
\hline S1R1 & Subang & Pineapple & 2018 \\
\hline P34E & Pemalang & Pineapple & 2018 \\
\hline $\mathrm{P} 33 \mathrm{~F}$ & Pemalang & Pineapple & 2018 \\
\hline S71 & Subang & Pineapple & 2018 \\
\hline S63 & Subang & Pineapple & 2018 \\
\hline P33C & Pemalang & Pineapple & 2018 \\
\hline S62 & Subang & Pineapple & 2018 \\
\hline 1736B & Central Lampung & Pineapple & 2017 \\
\hline S1R3 & Subang & Pineapple & 2018 \\
\hline 1710A1 & Central Lampung & Pineapple & 2017 \\
\hline
\end{tabular}

A deeper probe into the multilocus genotype analysis (Table 2) revealed that several isolates of $P$. nicotianae from Central Lampung and Blitar shared common MLGs, indicative of the same source of infection, which probably derived from the same pineapple seedling because the pineapple plantations in both Central Lampung and Blitar belong to one company.

The isolates from the non-pineapple host showed distinctive MLG compared to the pineapple counterparts and the rest of the populations. It is indicative of zero interaction between the non-pineapple and pineapple population.

Analysis of molecular variance (AMOVA) estimated the population differentiation directly from molecular data. The AMOVA of microsatellite genotypes data showed that the isolates had a low diversity among the population $(6 \%)$ but high diversity within the individual (Table 3), evidenced from the low number of Fst (0.056) that represents the variance of allele frequencies among populations. The result of allelic pattern analysis using Genalex software demonstrated that the private alleles were specific to a population. Central Lampung population had the highest frequency of private alleles which evolve only in specific places (Table 4). Additionally, Central Lampung had highest number of locally common alleles which take 
up $50 \%$ of the populations with $>5 \%$ frequency in a specific population. The highest Shannon's Information Index was in the non-pineapple group followed by Subang, Pemalang, Punggur, Central Lampung, and Blitar. A previous study also reported a high variability within the population in $P$. infestans collected in Nordic European countries (Brurberg et al. 2011).

The low number of Fst and percentage of variance (Table 3) indicated non-random mating or clonal reproduction in $P$. nicotianae associated with pineapple's decayed root. It is confirmed by allelic patterns that revealed private alleles in Lampung, Blitar, and Subang populations (Table 4). The private allele is most likely produced by clonal reproduction and geographic isolation. $P$. nicotianae can undergo sexual and asexual reproduction, thus taking advantage of the strictly asexual or sexual pathogens. Likewise, mitotic recombination is common among Phytophthora species. The pathogen is not necessarily performing sexual reproduction at any chance (Dobrowlski et al. 2003). The previous studies reported private alleles specific to certain populations due to clonal reproduction in P. infestans (Gavino et al. 2000; Montarry et al. 2010) and P. sojae (Wu et al. 2017) or due to geographic isolation as observed in P. alni (Aguayo et al. 2012).

The number of alleles was highest in Central Lampung population (3.167) followed by Blitar (2.833) Subang (2.667), and the non-pineapple group (2.500), while the least were Pemalang (2.167) and Subang (2.167) (Table 4). This allelic richness is indicative of a population's longterm potential for adaptability and persistence (Greenbaum et al. 2015). Therefore, the population of $P$. nicotianae in Central Lampung is more likely to be adaptive to the environmental change rather than the other populations.
Table 2. Multi Locus Genotype (MLG) frequencies per population

\begin{tabular}{|c|c|c|c|c|c|c|}
\hline \multirow[b]{2}{*}{ MLG } & \multicolumn{6}{|c|}{ Population } \\
\hline & $\stackrel{\leftrightarrows}{\leftrightarrows}$ & 泀晜 & 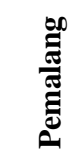 & 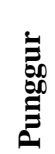 & 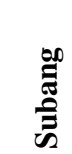 & 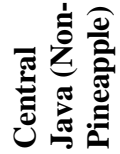 \\
\hline 1 & 0.15 & 0.03 & & & & \\
\hline 2 & 0.15 & 0.45 & & & & \\
\hline 3 & 0.02 & & 0.28 & 1 & & \\
\hline 4 & 0.02 & 0.09 & & & & \\
\hline 5 & 0.24 & 0.29 & & & & \\
\hline 6 & & & & & & 0.37 \\
\hline 7 & 0.05 & 0.03 & & & & \\
\hline 8 & & 0.06 & & & & \\
\hline 9 & 0.09 & 0.06 & & & & \\
\hline 10 & & & & & 0.40 & \\
\hline 11 & & 0.06 & & & & \\
\hline 12 & & & 0.42 & & & \\
\hline 13 & 0.02 & 0.06 & & & & \\
\hline 14 & & & & & 0.60 & \\
\hline 15 & & & 0.14 & & & \\
\hline 16 & & 0.03 & & & & \\
\hline 17 & 0.02 & & & & & \\
\hline 18 & 0.02 & & & & & \\
\hline 19 & & 0.03 & & & & \\
\hline 20 & & 0.03 & & & & \\
\hline 21 & & & & & & 0.12 \\
\hline 22 & & & 0.14 & & & \\
\hline 23 & & & & & & 0.12 \\
\hline 24 & & & & & & 0.12 \\
\hline 25 & & & & & & 0.12 \\
\hline 26 & & & 0.14 & & & \\
\hline 27 & & & & & & 0.12 \\
\hline
\end{tabular}

Table 3. Summary of analysis molecular variance

\begin{tabular}{lccccccc}
\hline Source & df & SS & MS & Est. Var. & \% & Fst & P-value \\
\hline Among Populations & 5 & 15.525 & 3.105 & 0.065 & $6 \%$ & 0.056 & 0.001 \\
Among Individuals & 92 & 118.383 & 1.287 & 0.192 & $17 \%$ & & \\
Within Individuals & 98 & 88.500 & 0.903 & 0.903 & $78 \%$ & \\
Total & 195 & 222.408 & & 1.159 & $100 \%$ & \\
\hline
\end{tabular}

Note: df: degree of freedom; SS: sum of squares; MS: mean square; Est. var. estimated variance; \%: percentage of variance, FST: Fixation Index.

Table 4. Allelic pattern across population

\begin{tabular}{lcccccc}
\hline Population & Central Lampung & Blitar & Pemalang & Punggur & Subang & $\begin{array}{c}\text { Central Java } \\
\text { (Non-pineapple) }\end{array}$ \\
\hline $\mathrm{Na}$ & 3.167 & 2.833 & 2.167 & 2.167 & 2.667 & 2.500 \\
$\mathrm{Ne}$ & 1.546 & 1.477 & 1.900 & 1.900 & 1.789 & 1.750 \\
$\mathrm{I}$ & 0.577 & 0.513 & 0.596 & 0.588 & 0.615 & 0.640 \\
No. Private Alleles & 0.167 & 0.167 & 0.000 & 0.000 & 0.167 & 0.000 \\
No. LComm Alleles $(<=50 \%)$ & 0.667 & 0.500 & 0.167 & 0.333 & 0.500 & 0.500 \\
$\mathrm{He}$ & 0.318 & 0.285 & 0.371 & 0.361 & 0.364 & 0.383 \\
uHe & 0.323 & 0.290 & 0.397 & 0.433 & 0.383 & 0.412 \\
\hline
\end{tabular}

Note: Na: No. of Different Alleles; Ne: No. of Effective Alleles; I: Shannon's Information Index; No. Private Alleles: No. of Alleles Unique to a Single Population; No. LComm Alleles $(<=50 \%)=$ Number of Locally Common Alleles (Freq. $>=5 \%)$ Found in $50 \%$ or Fewer Populations; He: Expected Heterozygosity; uHe: Unbiased Expected Heterozygosity 
Shannon's information index is a vital criterion to understand the population variation because it distinguishes genetic diversity in a population combining abundance and evenness (Ali et al. 2019). Table 4 shows that Shannon's information index (I) in this study was generally high $(0.513$ to 0.640$)$, indicative of high genetic variance and even distribution across populations. The highest was the non-pineapple group (0.640), followed by the pineapple group from Subang (0.615), Pemalang (0.596), Punggur (0.588), Central Lampung (0.577), and Blitar (0.513). It is evident that the population in Subang had higher and more evenly distributed genetic variance compared to that in Central Lampung.

The expected heterozygosity $(\mathrm{He})$ was ranging between 0.383 to 0.318 (Table 4). The highest was group isolates collected from the non-pineapple plants $(0.383)$ followed by the pineapple associated isolates collected from Pemalang (0.371), Subang (0.364), Punggur (0.361), Central Lampung (0.318), and Blitar (0.285). The expected heterozygosity was used to assess genetic variation within populations. Estimation of this statistic could decrease in accuracy and precision when individuals are related or inbreed due to increasing dependence among allele copies in the sample (Harris and DeGiorgio 2016). Since $P$. nicotianae reproduction mostly by asexual rather than sexual, we calculated the unbiased expected heterozygosity and found that it ranged from 0.290 to 0.433 (Table 4). The highest was the population of $P$. nicotianae isolated from pineapple in Punggur (0.43) followed by the isolates collected from the non-pineapple (0.412), Pemalang population (0.397), Subang (0.383), Central Lampung (0.323), and Blitar (0.290).

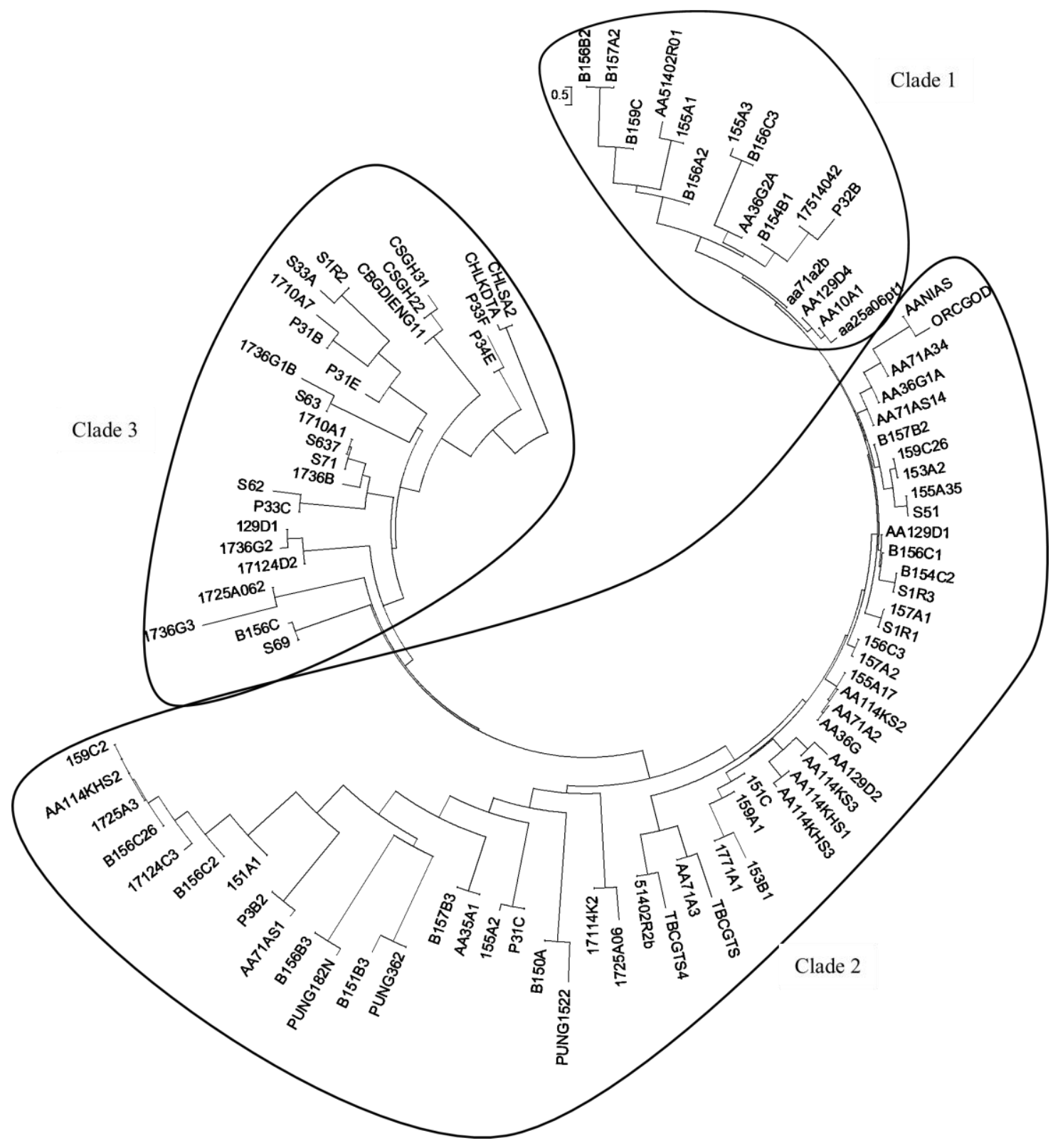

Figure 1. Phylogenetic analyses of $P$. nicotianae constructed with Neighbor-Joining Algorithm using MEGA 6 was showed 3 major clades 
The phylogenetic tree constructed with the neighborjoining algorithm showed three major clades. The first and second clade were dominated by isolates associated with heart rot disease in pineapple, while the third clade consisted of isolates from the non-pineapple group (Figure 1). The first clade consisted of $16 P$. nicotianae isolates from Blitar and Central Lampung, collected from pineapple plantations owned by the same private company which utilized vegetative propagation for pineapple cultivation and used the same source of planting materials. It explains the closer relationship between P. nicotianae in Blitar and Central Lampung.

The second clade had the most $P$. nicotianae isolates dominated by pineapple host in Central Lampung, Blitar, and Punggur, while the third clade had isolated from Subang, Pemalang, and the non-pineapple group. All nonpineapple isolates were collected from areas in Central Java which is in close proximity to Pemalang and Subang. Also, Central Lampung is relatively close to Punggur within Lampung Province.

It is evident from Figure 1 that most of the isolates from the same geographical origin are grouped into the same clade, while several other isolates from one population are scattered in the other clades. Most isolates collected from the non-pineapple plants show a distant relationship with pineapple isolates (Figure 1). The inconsistency of genotypic structure and geographical origin are common on demographic analysis of Phytophthora species, previous studies on $P$. nicotianae from various host and locations across Japan (Afandi, et al. 2019), P. nicotianae isolated on citrus (Biasi et al. 2016), P. Plurivora (Schoebelet al. 2014), and P. colocasiae (Nath et al. 2013) also showed moderate to high genetic diversity without consistency on the geographical origin. Pathogen transmission from one area to another may use human as their transporting agent. Since $P$. nicotianae is soil and waterborne and may long survive as chlamydospore for a long time, it is highly transmissible via agricultural products or water flow.

The isolates were obtained from different pineapple varieties. The private company in Central Lampung and Blitar planted the smooth cayenne variety, while the local farmers in Punggur, Subang, and Blitar planted the queen variety. To the best of our knowledge, there is no evidence of relationship between $P$. nicotiana genotypes and pineapple variety.

In conclusion, we reported a distinct genetic distance of $P$. nicotianae associated with root rot disease in the isolates of pineapple and the non-pineapple group. However, the low percentage of variance between $P$. nicotianae and other populations that shared common MLG indicated a gene flow between populations.

\section{ACKNOWLEDGEMENTS}

We would like to thank PT. Great Giant Pineapple, The Head of Belik Village, Pemalang, Indonesia and all colleagues for their contribution in data sampling. This research is a part of dissertation of the first author in the
Ph.D. Double Degree Program between the United Graduate School of Agricultural Sciences Gifu University, Japan and the Program of Biotechnology, Graduate School of Universitas Gadjah Mada, Indonesia under MEXT Scholarship, Japan.

\section{REFERENCES}

Afandi A, Hieno A, Wibowo A, Subandiyah S, Afandi, Suga H, Tsuchida K, Kageyama K. 2019. Genetic diversity of Phytophthora nicotianae reveals pathogen transmission mode in Japan. J Gen Plant Pathol 85: 189-200. DOI: 10.1007/s10327-018-00836-4.

Ali F, Yilmaz A, Nadeem MA, Habyarimana E, Subasi I, Nawaz MA, Chaudhary HJ, Shahid MQ, Ercisli S, Zia MAB, Chung G, Baloch FS. 2019. Mobile genomic element diversity in world collection of safflower (Carthamus tinctorius L.) panel using iPBS-retrotransposon markers. PLoS One 14 (2): e0211985. DOI: 10.1371/journal.pone.0211985.

Aguayo J, Adams GC, Halkett, F, Catal M, Husson C, Nagy ZÁ, Hansen EM, Marçais B, Frey P. 2013. Strong genetic differentiation between North American and European populations of Phytophthora alni subsp. uniformis. Phytopathology 103 (2): 190-199. DOI: 10.1094/PHYTO-05-12-0116-R.

Biasi A, Martin FN, Cacciola SO, Di San Lio GM, Grunwald NJ, Schena L. 2016. Genetic analysis of Phytophthora nicotianae populations from different hosts using microsatellite markers. Phytopathology 106 (9): 1006-1014. DOI: 10.1094/PHYTO-11-15-0299-R.

Bush EA, Stromberg EL, Hong C, Richardson PA, Kong P. 2006. Illustration of key morphological characteristics of Phytophthora species identified in Virginia Nursery Irrigation Water. Plant Health Prog 7 (1). DOI:10.1094/PHP-2006-0621-01-RS.

Bruberg MB, Elameen A, Le VH, Nærstad R, Hermansen A, LehtinenA, Hannukkala A, Nielsen B, Hansen J, Andersson B, Yuen J. 2011. Genetic analysis of Phytophthora infestans populations in the Nordic European countries reveals high genetic variability. Fungal Biol 115: 335-342.

Chowdappa P, Kumar BJN, Kumar SPM, Madhura S, Bhargavi BR, Lakshmi MJ. 2016. Population structure of Phytophthora nicotianae reveals host-specific lineages on Brinjal, Ridge Gourd, and Tomato in South India. Phytopathology 106 (12): 1553-1562. DOI: 10.1094/PHYTO-04-14-0099-R.

Dobrowolski MP, Tommerup IC, Shearer BL, O'Brien PA. 2003. Three clonal lineages of Phytophthora cinnamomi in Australia revealed by microsatellites. Phytopathol 93: 695-704. DOI: 10.1094/PHYTO.2003.93.6.695.

Gavino PD, Smart CD, Sandrock RW, Miller JS, Hamm PB, Lee TY, Davis RM, Fry WE. 2000. Implications of sexual reproduction for Phytophthora infestans in the United States: Generation of an aggressive lineage. Plant Dis 84 (7): 731-735. DOI: 10.1094/PDIS.2000.84.7.731.

Green J, Nelson S. 2015. Heart and root rots of pineapple. Plant Disease. Collage of Tropical Agriculture and Human Resources, University of Hawai'i, Hawai'i.

Greenbaum G, Templeton AR, Zarmi Y, Bar-David S. 2015. Alllic richness following population founding events-a stochastic modeling framework incorporating gene flow and genetic drift. PLoS One 9 (12): e115203. DOI: 1371/journal.pone.0115203.

Harris AM, DeGiorgio M. 2016. An unbiased estimator of gene diversity with improved variance for sample containing related and inbred individuals of any ploidy. Genes Genomes Genetics 7 (2): 671-691. DOI: $10.1534 / \mathrm{g} 3.116 .037168$.

marHong CX, Moorman GW. 2005. Plant pathogens in irrigation water: challenges and opportunities. Crit Rev Plant Sci 24: 189-208. DOI: 10.1080/07352680591005838.

Jung T, Orlikowski L, Henricot B, Abad-Campos P, Aday AG, Aguín Casal O, Bakonyi J, et al. 2016. Widespread Phytophthora infestations in European nurseries put forest, semi-natural and horticultural ecosystems at high risk of Phytophthora diseases. For Path 46: 134-163. DOI: 10.1111/efp.12239

Li Y, Harris-Shultz K, Wang H, Wadl PA, Ji P. 2017. Population structure and genetic diversity of Phytophthora nicotianae from Tobacco in 
Georgia. Plant Dis 101 (7): 1113-1118. DOI: 10.1094/PDIS-01-170142-RE.

Montarry J, Andrividon D, Glais I, Corbiere R, Mialdea G, Delmotte F. 2010 Microsatellite markers reveal two admixed genetic groups and an ongoing displacement within the French population of the invasive plant pathogen Phytophthora infestans. Mol Ecol 19: 1965-1977. DOI: $10.1111 / \mathrm{j} .1365-294 X .2010 .04619 . x$.

Nath, V.S., Hegde, V.M., Jeeva, M.L, Misra RS, Veena SS, Raj M, Sankar DS. 2015. Morphological, pathological and molecular characterization of Phytophthora colocasiae responsible for taro leaf blight disease in India. Phytoparasitica 43: 21-35. DOI 10.1007/s12600-014-0422-5.

PanabièresF, Ali GS, Allagui MB, Dalio RJD, Gumedstad NC, Kuhn ML, Guharoy S, Schena L, Zampounis A. 2016. Phytophthora nicotianae diseases worldwide: new knowledge of a long-recognised pathogen. Phytopathol Mediterr 55 (1): 20-40. DOI 10.14601/Phytopathol_Mediterr-16423.

Peakall R, Smouse PE. 2012. GENALEX 6.5: genetic analysis in EXCEL. Population genetic software for teaching and research - an update. Bioinformatics 28: 2537-2539. DOI: 10.1093/bioinformatics/bts460.

Radmer L, Anderson G, Malvick DM, Kurle JE, Renhal A, Malik A 2017. Pythium, Phytophthora, and Phytopythium spp. Associated with Soybean in Minnesota, their relative aggressiveness on soybean and corn, and their sensitivity to seed treatment fungicides. Plant Dis 101 (1): 62-72. DOI: 10.1094/PDIS-02-16-0196-RE.
Ratti MF, Ascunce MS, Landivar JJ, Goss EM. 2018. Pineapple heart rot isolates from Ecuador reveal a new genotype of Phytophthora nicotianae. Plant Pathol 67(8): 1803-1813. DOI: 10.1111/ppa.12885

Schoebel CN, Stewart J, Gruenwald NJ, Rigling D, Prospero S. 2014. Population History and Pathways of Spread of the Plant Pathogen Phytophthora plurivora. PLOS ONE 9 (1): e85368. DOI: 10.1371/journal.pone.0085368.

Tamura K, Stecher S,Peterson D, Filipski A, Kumar S. 2013. MEGA6: Molecular Evolutionary Genetics Analysis Version 6.0. Mol Biol Evol 30 (12): 2725-2729. DOI: 10.1093/molbev/mst197.

Vettraino AM,Lucero G,Pizzuolo P, Franceschini S, Vannini A. 2009. First report of root rot and twigs wilting of olive trees in Argentina caused by Phytophthora nicotianae. Plant Dis 93 (7): 765-765. DOI: 10.1094\%2FPDIS-93-7-0765B.

Waterhouse GM, Waterston JM. 1964a. CMI Descriptions of Pathogenic Fungi and Bacteria no. 34, Phytophthora nicotianae var. nicotianae. CABI, Wallingford, UK.

Waterhouse, G. M., and Waterston, J. M. 1964b. CMI Descriptions of Pathogenic Fungi and Bacteria no. 35, Phytophthora nicotianae var. parasitica. CABI, Wallingford, UK.

Wu M, Li B, Liu P, Weng Q, Zhan J, Chen Q. 2017. Genetic analysis of Phytophthora sojae populations in Fujian, China. Plant Pathol 66: 1182-1190. DOI: 10.1111/ppa.12666. 